\title{
Participatory assessment of the Toliara Bay reef fishery, southwest Madagascar
}

\author{
Ambroise Brenier', Jocelyne Ferraris' and Jamal \\ Mahafina"
}

\begin{abstract}
In order to ensure the sustainable management of reef fisheries, it is necessary to obtain data about the impacts of these fisheries on both fish resources and the ecosystems that sustain them. Ecosystem-based surveys provide such information, but are difficult to implement because of high technical, financial and human resource requirements. In this regard participatory assessment methods have the potential to increase the amount of data collected at low cost, while taking advantage of local traditional ecological knowledge. In order to investigate the reef fishery of Toliara Bay, southwest Madagascar, we used participatory fish survey and interview data collected on site. These methods included: (i) monitoring of catch landings over six months by wholesale fish merchants, (ii) household surveys of fishing catch and effort, and fish consumption conducted by school children, and (iii) semi-structured interviews of reef users. The landings of 1,586 fishing trips were sampled between September 2006 and February 2007, 326 households were surveyed by trained school children in January 2007, and 70 reef users were interviewed in July/August 2006. Data collected by participants were compiled and compared to reference values when available, allowing an assessment of the sustainability of the reef fishery. The results of this study confirm the unsustainable nature of resource exploitation and underline the need for rapid management responses in order to reverse this trend. It also highlights the great potential of participatory assessment methods for gathering large amounts of relevant information on the status and evolution of the ecosystem upon which the fishery depends, while promoting education and awareness about the conservation and sustainable use of natural resources.
\end{abstract}

\section{RÉSUMÉ}

Bien que les pêcheries récifales ne contribuent que marginalement aux captures de pêche mondiales, elles restent une source majeure de revenus et de protéines pour des millions de personnes, en particulier dans les pays en voie de développement. Afin de s'assurer de la bonne gestion de ces pêcheries, il est nécessaire de disposer d'informations sur l'état des ressources et des écosystèmes dont elles dépendent. Mener de telles études est d'autant plus compliqué que les pêcheries en milieu

\author{
Correspondence: \\ Ambroise Brenier \\ Institut de Recherche pour le Développement/École Pratique \\ des Hautes Études, Université de Perpignan \\ 66860 Perpignan cedex, France \\ E-mail: ambroise.brenier@gmail.com
}

corallien portent sur un large éventail de stocks et d'espèces de poissons, concernent de nombreux pêcheurs et supposent diverses méthodes de captures, et empruntent un grand nombre de canaux de distribution. De plus, ces pêcheries sont souvent considérées de moindre valeur par les gouvernements qui leur octroient donc peu de moyens humains et financiers. Face à ces problèmes, l'implication de la société civile dans les programmes de suivi, appelé suivi participatif, semble en mesure d'apporter des solutions, d'autant que les suivis participatifs présentent l'avantage d'accroître le nombre de données collectées à moindre coût, tout en profitant des connaissances écologiques empiriques qui sont disponibles localement. Afin d'évaluer la pérennité de la pêcherie récifale de la baie de Toliara dans le sud ouest de Madagascar, des méthodes de suivi participatif ont été expérimentées. Ces méthodes consistent à mettre en œuvre : (i) des suivis des débarquements pendant six mois impliquant des mareyeuses, (ii) des enquêtes auprès des ménages, réalisées par des écoliers préalablement formés, afin de recueillir des informations sur l'effort de pêche, les captures et la consommation de poisons, (iii) des entretiens semi-directifs avec des usagers du milieu marin. Ainsi, entre 2006 et 2007, 1586 sorties de pêche ont été échantillonnées, et 326 ménages et 70 usagers ont fait l'objet d'enquêtes. Les données collectées par les membres de la communauté locale ont été analysées afin d'évaluer la pérennité de la pêcherie dans la baie de Toliara. Les résultats de l'étude confirment une exploitation non pérenne et soulignent la nécessité de mettre en place des mesures de gestion afin d'inverser la tendance de détérioration des écosystèmes de la baie. II ressort également de cette étude que l'implication de la société civile s'avère être pertinente pour recueillir des informations sur les pêcheries récifales à faible coût. En effet, de part le nombre, la qualité, la variété et la pertinence des informations produites, les suivis participatifs contribuent utilement à l'évaluation des pêcheries récifales. Cette expérience met également en évidence le fort potentiel des suivis participatifs à contribuer au renforcement des connaissances et des capacités des communautés locales dans le domaine de la gestion des ressources marines. Ainsi, face au difficile contexte socio-économique et politique qui prévaut actuellement à Madagascar, cette approche s'avère 


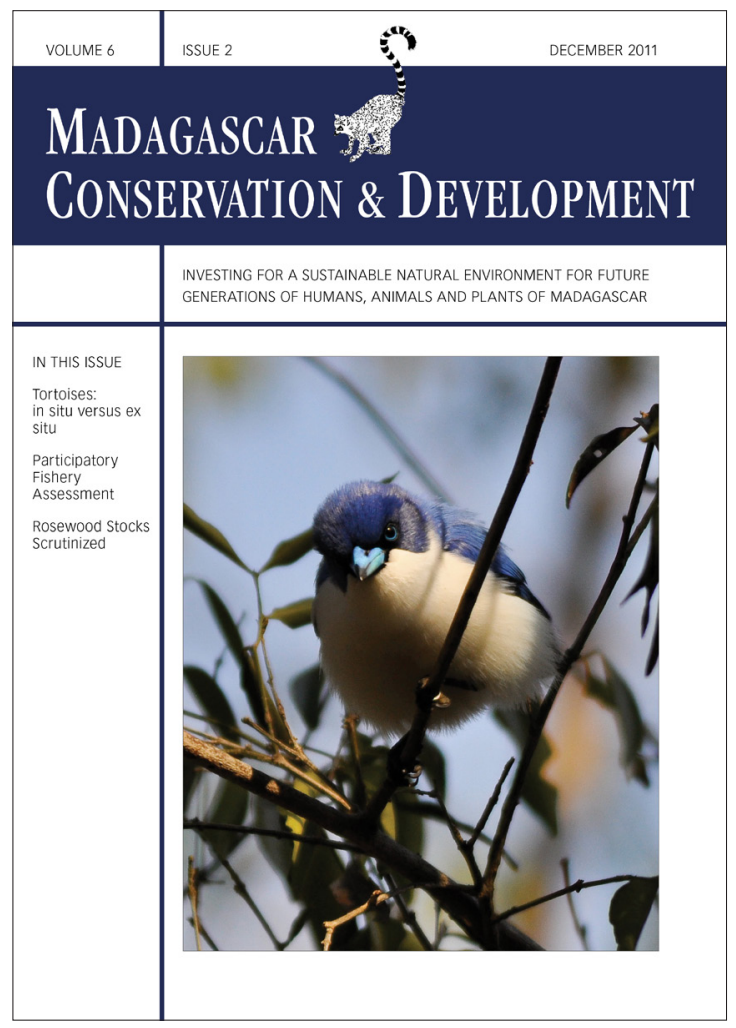

Madagascar Conservation \& Development is the journal of Indian Ocean e-Ink. It is produced under the responsibility of this institution. The views expressed in contributions to MCD are solely those of the authors and not those of the journal editors or the publisher.

All the Issues and articles are freely available at http://www.journalmcd.com

Contact Journal MCD

info@journalmcd.net for general inquiries regarding MCD funding@journalmcd.net to support the journal

Madagascar Conservation \& Development Institute and Museum of Anthropology University of Zurich

Winterthurerstrasse 190

CH-8057 Zurich, Switzerland

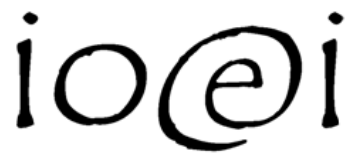

Indian Ocean e-Ink

Promoting African Publishing and Education www.ioeink.com

Missouri Botanical Garden (MBG)

Missouri Botanical Garden

Madagascar Research and Conservation Program BP 3391

Antananarivo, 101, Madagascar 
particulièrement prometteuse pour améliorer la gestion des pêcheries traditionnelles grâce à la production d'informations sur ces pêcheries et une plus grande implication des communautés locales dans le processus de gestion.

\section{INTRODUCTION}

Although coral reef fisheries account for a small proportion of global fisheries catches (Pauly et al. 2003), these small-scale fisheries are a major source of income and protein for millions of people, especially in developing countries (Sadovy 2005). coral reef ecosystems are, however, severely degraded worldwide, and overexploitation is one of the major threats they face (Jackson et al. 2001). Fisheries have an impact on the resources targeted and can also cause severe damage to non-target species, habitats, structures and functions in marine ecosystems. There is therefore a critical need to manage fisheries in a way that maximizes individual species yields in the long term while minimizing impacts on ecosystem components, structures and functions, thus securing the sustainability of the fishery. This is the biological objective of a successful fishery, which should also achieve economic efficiency and social objectives (Hilborn 2007). In order to achieve this objective, information is needed on the status of the exploited resources and the ecosystem components that sustain these resources in order to undertake ecosystem-based management (FAO 2003).

Assessing the biological sustainability of reef fisheries is a difficult task for at least five reasons: (i) reef fisheries are complex, relying on a wide variety of target species, gear types, landing areas and distribution routes; (ii) generally, governments do not spend large amounts of money on the management of reef fisheries; (iii) when financial and human resources are scarce, monitoring and evaluation programs are neglected because of their cost and complexity; (iv) ecosystem-based management requires information not only on the status of target species, but also other ecosystem components or processes, with intensive data requirements; $(v)$ there is a lack of historical information on resources and ecosystem status and trends which hinders the interpretation of recently collected data (Zeller et al. 2006).

In the face of such challenges, the involvement of local communities in the assessment of reef fisheries sustainability (participatory assessment) has proved to be useful for several reasons: (i) it increases sampling effort in space and time, making participatory assessment especially effective for broad scale surveys; (ii) it is cost-effective because it usually involves volunteers and takes advantage of their logistical resources; (iii) it takes advantage of the traditional ecological knowledge and skills of resource users (Obura et al. 2002).

This approach could be particularly appropriate for obtaining information on small-scale fisheries in Madagascar. Indeed statistics for these fisheries, which employ about 100,000 fishers in Madagascar, are scarce (Le Manach et al. 2012). Further, these fisheries are often active in remote areas where few research resources are available. The purpose of participatory assessment is to fill information needs by generating a general understanding of the scale, composition and trends of these fisheries, to guide the implementation and assessment of fisheries regulations and management plans. The value of participatory methods in providing such information has been assessed in larger-scale research involving several case studies (Brenier 2009). In this paper, we will discuss the applica- bility of easy-to-use participatory methods for gaining rapid knowledge of Madagascar's small-scale fisheries at low-cost. For this purpose we tested several participatory methods to assess the biological sustainability of the reef fishery of Toliara Bay in southwest Madagascar. The second objective of the study is to characterize the on-going evolution of the Toliara Bay fishery and its ecological impacts. This fishery was described in 1989/1990 (Laroche and Ramananarivo 1995), and about two decades later we have the opportunity to re-assess the ecological sustainability of the Toliara Bay reef fishery and characterize its evolution.

STUDY SITE. Supporting more than 140,000 inhabitants

in the 1990s (Vasseur 1997), Toliara Bay in southwest Madagascar is bordered by the Fiherenana delta to the north and by the Onilahy estuary to the south (Figure 1). This bay encompasses the most diverse coral reef formations of the southwest coast of Madagascar and consists of two barrier reefs (the Grand Récif of Toliara, an $18 \mathrm{~km}$ long barrier reef, and Nosy Tafara in the south), two coral banks (Mareana, Ankilibe), three lagoon reefs (Norikazo, Dimadimatse, Beloza) and one fringing reef (Pichon 1978). Mangrove forests occur along the shoreline between the Onilahy and Fiherenana rivers. Two main seasons influence the temporal variability of the area: the austral summer from November to April, a warm season with occasional rains, and the austral winter from May to October, a cold and dry season. The small-scale (or traditional) fishery of Toliara Bay uses only unpowered traditional canoes with a single outrigger and a square sail, and, in most cases, only one of the following three fishing methods: hand-line, gill-net or seine (Laroche and Ramananarivo 1995). In Madagascar the term traditional or small-scale fisheries refers to non-motorized, kinship-based fishing for subsistence or for local markets (Mathew 2002). In Toliara Bay dugout canoes three meters long are usually used by one man practicing line fishing, and dugout canoes four to eight meters long are usually used by two to four men practicing gill-net fishing, or at least three people practicing seine fishing. From north to south there are six main landing sites: the fishing districts of Ambohitsabo/Besakoa, Mahavatse II and Ankiembe/Mahavatse I, and the villages of Ankilibe, Sarodrano and Saint Augustin (Figure 1). About 1,500 subsistence fishers exploit this coastline (Laroche and Ramananarivo 1995). Women and children also practice reef gleaning on foot on the reef flats of Toliara Bay during low tides (Vasseur 1997).

\section{METHODOLOGY}

The study of the relevance of participatory methods to reef fisheries assessment was part of a larger research project involving three case studies. At each site, including Toliara Bay, we followed a four-step process. The first step was to test the participatory methods in the field in order to assess their feasibility. The second step of the process dealt with the assessment of the community members' commitment to the monitoring activities. The third step consisted of an assessment of the credibility of the data collected by the community members for each method. The last step involved examining the relevance and usefulness of the data obtained through participatory methods for assessing the state of reef fisheries. In this study we will discuss more specifically the applicability of participatory methods for assessing Madagascar's small-scale fisheries, based on our research in Toliara Bay. 


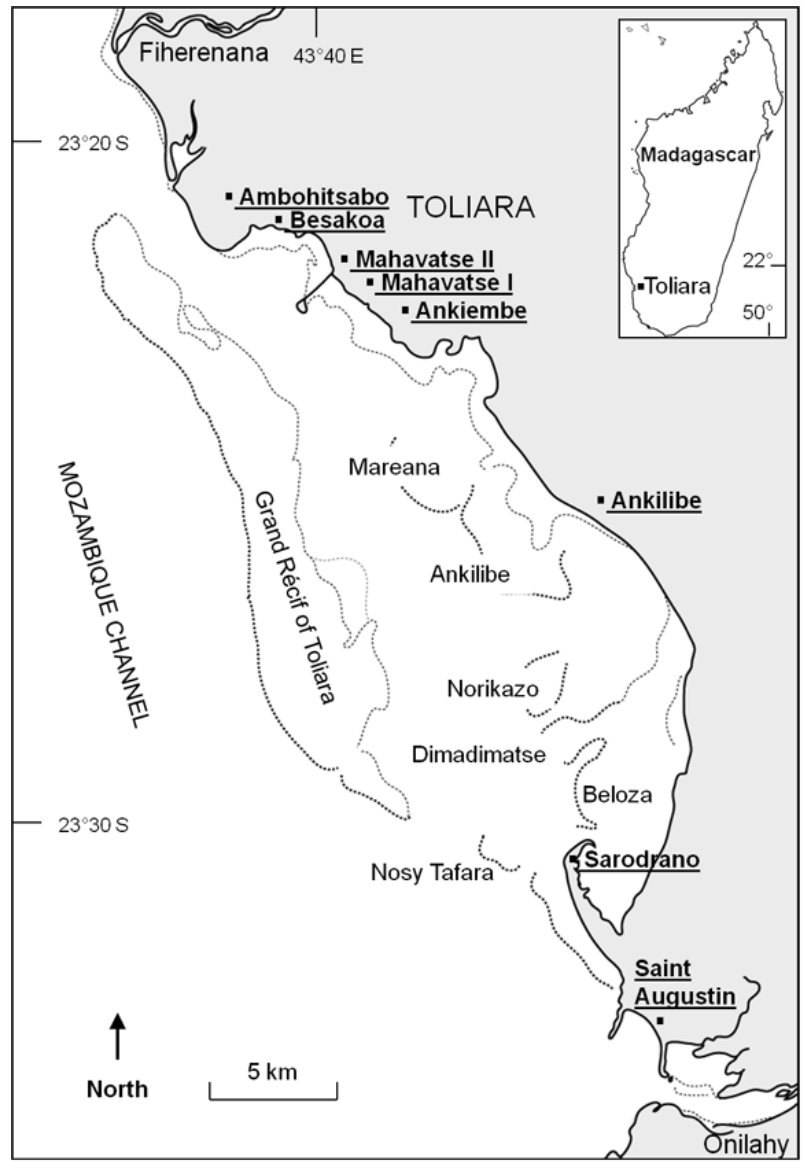

FIGURE 1. Map of Toliara Bay. Barrier reefs are represented by Grand Récif of Toliara and Nosy Tafara, coral banks by Mareana and Ankilibe, lagoon reefs by Norikazo, Dimadimatse and Beloza and fringing reef are lining the Sarodrano peninsula. The underlined names show location of the fishing villages and districts.

In order to meet both objectives of our study and after reviewing the available literature dealing with commonly-used methods for participatory monitoring programs of coral reef ecosystems and fisheries (Table 1), and checking local constraints and logistical feasibility in Toliara, we selected three participatory methods to implement in Toliara Bay: (i) catch landing monitoring by wholesale fish merchants; (ii) household survey of fishing catch and effort, and fish consumption, conducted by school children; (iii) semi-structured interviews of reef users.

LANDING MONITORING. In Toliara Bay, the women

involved in the fish trade live near the beaches where the fish are landed and work there every fishing day. They wait for the fishers to bring their catch back to the beach in order to purchase fish for resale at the markets in Toliara. Three female fish sellers working on Ankiembe beach, the main landing site of Toliara bay where $40 \%$ of the fishing gears are registered (Laroche and Ramananarivo 1995), were chosen and trained to carry out landings surveys in addition to their daily work. After testing their knowledge regarding the identification of the various fish species, an Ankiembe beach catch landing monitoring protocol was put forward to them. In order to estimate the catch per unit effort (CPUE) and catch composition for each fishing gear, the monitoring was carried out every fishing day for six months, covering part of the two main seasons between September 2006 and February 2007. Every fishing day, while still doing their normal work, these three women were asked to collect data from at least nine randomly chosen fishing boats landing on Ankiembe beach. For each sampling unit (landing boat), the number of fishers, the fishing site, the gear used and a visual estimation of the weight of each species caught were recorded. In total, 1,586 fishing trips were sampled (4.3\% of all the fishing boats landing at Ankiembe). From August 1989 to February 1990 an investigator recorded exactly the same parameters, on the same landing beach, by sampling fifteen landing boats twenty days per month (Laroche and Ramananarivo 1995). Comparison of the two studies allows us to describe the general evolution of the fishery over the last two decades.

HOUSEHOLD SURVEY. After a short training class, children

of about ten years old from primary schools of fishing districts and villages along the coast of Toliara Bay were asked to conduct a survey in their own household and to return the questionnaires at school a few days later. This method relies on school children to collect fishing activity information from their respective households using a questionnaire, which is distributed and explained to them in detail at school. The training session at school was half a day long for each class, and allowed us to explain the objective of the study and to make sure that all children understood how to complete the survey once at home. All children from 12 classes from all of the eight public primary schools in the eight fishing districts and villages along the coast of Toliara Bay were involved in conducting surveys. We chose very young students in order to avoid bias due to withdrawal from school of children from the most vulnerable families in older classes (Hosch 2000), especially fishers' families that tend to prioritize the involvement of teenagers in household fishing activity instead of sending them to school. Thus, by targeting these school classes, we assumed that all children are attending school at this age, in order to survey a representative sample of households. This method seeks to gather information on fishing effort, fishery yield, catch composition and fish consumption based on declarations of household members. Some questions of the questionnaire were designed for the whole household (size of the household, fish consumption, number of canoes, number of fishers and number of women practicing reef gleaning living in the household). Other questions were asked to one fisher or one woman practicing reef gleaning of the household about fishing frequencies, fishing gears, fishing areas, species and quantity usually caught, and the use of their catches (Supplementary Material S1). Three hundred and twenty six questionnaires were correctly completed and returned (86\% of the questionnaires distributed in classes), which represents a sample size of $10.3 \%$ of all the households in the fishing districts and villages along the coast of Toliara Bay.

PERCEPTION SURVEY. The third method involved

semi-structured interviews and was conducted with reef and lagoon users with long fishing experience. Semi-structured interviews are more conducive to interaction and mutual confidence between the interviewee and the interviewer than questionnaires, and are especially suitable for the gathering of traditional ecological knowledge (Huntington 1998). We selected key informants by snowball sampling (Henry 1990) in each fishing district and village along the coast of Toliara Bay. Seventy interviews were conducted in July/August 2006. These interviews were two hours and twenty minutes long on average. The mean number of years of reef use by the informants was 31. Interviewees were asked about their perceptions of key 
TABLE 1. Participatory monitoring methods commonly used to assess coral reef ecosystems and reef fisheries.

\begin{tabular}{|c|c|c|c|c|c|}
\hline Objective & Method & Participant & Pros & Cons & Reference \\
\hline $\begin{array}{l}\text { To obtain subsistence } \\
\text { fishery statistics }\end{array}$ & $\begin{array}{l}\text { Questionnaire on house- } \\
\text { hold socio-economic } \\
\text { characteristics and one } \\
\text { week daily log sheets of } \\
\text { household seafood } \\
\text { consumption, fishing trips } \\
\text { and catch characteristics }\end{array}$ & $\begin{array}{l}\text { Fourteen to } \\
\text { eighteen } \\
\text { years old } \\
\text { school students }\end{array}$ & $\begin{array}{l}\text { Short time broad scale } \\
\text { survey, } \\
\text { Large educational bene- } \\
\text { fits }\end{array}$ & $\begin{array}{l}\text { Households sampled were } \\
\text { not representative of all } \\
\text { households } \\
\text { small portion of log } \\
\text { sheets answered satis- } \\
\text { factorily }\end{array}$ & (Hosch 2000) \\
\hline $\begin{array}{l}\text { To detect ecological } \\
\text { changes in coral reef } \\
\text { ecosystems }\end{array}$ & $\begin{array}{l}\text { Underwater visual census } \\
\text { of key components of } \\
\text { coral reef ecosystems }\end{array}$ & $\begin{array}{l}\text { Recreational divers } \\
\text { Fishers } \\
\text { Community members }\end{array}$ & $\begin{array}{l}\text { Standardized protocols } \\
\text { do exist allowing global } \\
\text { scale surveys }\end{array}$ & $\begin{array}{l}\text { Need of intense training } \\
\text { Surveys are time consum- } \\
\text { ing for the participants }\end{array}$ & $\begin{array}{l}\text { (e.g., Pattengill, } \\
\text { Semmens } \\
\text { \& Semmens 2003) }\end{array}$ \\
\hline $\begin{array}{l}\text { To identify historical } \\
\text { trends in coral reef } \\
\text { ecosystem components } \\
\text { and fishery activity }\end{array}$ & $\begin{array}{l}\text { Questionnaire on local } \\
\text { resource user perceptions } \\
\text { of trends in coral reef } \\
\text { ecosystem components } \\
\text { and fishery activity }\end{array}$ & $\begin{array}{l}\text { Resource user } \\
\text { (especially fishers) }\end{array}$ & $\begin{array}{l}\text { Long term scientific } \\
\text { studies are very rare } \\
\text { Knowledge of past } \\
\text { trends is critical }\end{array}$ & $\begin{array}{l}\text { Subjective qualitative } \\
\text { data }\end{array}$ & $\begin{array}{l}\text { (e.g., Webb et al. } \\
\text { 2004) }\end{array}$ \\
\hline $\begin{array}{l}\text { To obtain fishery } \\
\text { statistics }\end{array}$ & Fishery logbooks & Fishers & $\begin{array}{l}\text { Direct data of fishing } \\
\text { trips and catch charac- } \\
\text { teristics }\end{array}$ & $\begin{array}{l}\text { Objectivity of the par- } \\
\text { ticipants is questionable } \\
\text { High number of fishers } \\
\text { should be involved }\end{array}$ & $\begin{array}{l}\text { (e.g., Uychiaoco et } \\
\text { al. 2005) }\end{array}$ \\
\hline $\begin{array}{l}\text { To obtain fishery } \\
\text { statistics }\end{array}$ & Landing surveys & Fishers & $\begin{array}{l}\text { Direct data of fishing } \\
\text { trips and catch } \\
\text { characteristics }\end{array}$ & $\begin{array}{l}\text { Difficult to implement for } \\
\text { reef fisheries with high } \\
\text { number of landing points }\end{array}$ & $\begin{array}{l}\text { (e.g., Obura et al. } \\
\text { 2002) }\end{array}$ \\
\hline
\end{tabular}

trends in resources, habitats, environmental parameters and fishing effort over the past three decades. In order to triangulate the information collected through these perception surveys, only trends observed by at least $50 \%$ of the informants were considered further in our analysis. This allowed the identification of potential indicators of the level of fishery threats (e.g., perceived trends in the number of fishers, canoes, fishing trip frequency), fishery impacts (e.g., perceived changes in fishery resources abundance and size, proportion of the catch kept for subsistence consumption, mean weight of the catch per fishing trip) or fishing activity response (e.g., increase in fishing trip duration).

\section{RESULTS}

LANDING MONITORING. The catch landing monitoring revealed a higher CPUE for seine fishing $(9.4 \pm 0.8$ $\mathrm{kg} /$ fisher / trip) than for gill - net fishing $(7.9 \pm 0.7 \mathrm{~kg} /$ fisher / trip) and line fishing $(6.3 \pm 0.5 \mathrm{~kg} /$ fisher / trip). All results are given with a $95 \%$ confidence interval. Because of potential inaccuracies in line catch weight estimation by wholesale fish merchants, we could not calculate the composition of the catch from line fishing during the cold season (May to October). Thanks to the distribution of scales we were able to address this problem before the start of the warm season. Scombridae (36.8\%) represent one-third on the fish biomass caught by line during the warm season. Loliginidae $(16.7 \%)$, Lethrinidae (11.0\%), Carangidae (8.6\%) and Siganidae (7.6\%) also represent significant proportions of warm season line fishing catch. There was distinct seasonal variation in the composition of the fish caught with gill-nets between the two seasons. Catch was strongly dominated by Clupeidae $(61.2 \%)$ and Acanthuridae (18.2\%) during the cold period, and by Lethrinidae (45.6\%) and Acanthuridae (41.3\%) during the warm period. Clupeidae, Engraulidae and Carangidae were the dominant families caught by seine fishing throughout the year (Supplementary Material S2).
HOUSEHOLD SURVEY. The household surveys indicate that there were $1,970 \pm 438$ fishers and 1,902 \pm 317 canoes along the coast of Toliara Bay. The CPUE was $7.4 \pm 1.2$ $\mathrm{kg}$ / fisher / trip with a mean fishing trip length of $6.4 \pm 0.2$ hours and a departure and arrival time depending on the tides (Table 2). The proportion of the catch kept for subsistence consumption was $26 \%$. With the results of the household survey we were able to estimate a total production for the Toliara Bay fishery at $2,700 \pm 436$ million tons per year ( $\mathrm{mt} / \mathrm{y}$ ), and the annual yield at $14.2 \pm 2.3 \mathrm{mt} / \mathrm{y} / \mathrm{km}^{2}$. This estimation did not include the production of $955 \pm 166 \mathrm{mt} / \mathrm{y}$ by the $570 \pm 205$ women practicing reef gleaning with a CPUE of $14.4 \pm 2.5 \mathrm{~kg} /$ woman / trip. This fishing activity on reef flats mostly targets sea cucumbers, octopuses and clams. The quantity of fish consumed in the fishing districts and villages was estimated as $50 \pm 4 \mathrm{~kg} /$ inhabitant / y, which highlights the importance of the fishery for protein supply.

TABLE 2. Results of the household survey in the fishing disctricts and villages along the coast of Toliara Bay ( $n=326$ households).

\begin{tabular}{|c|c|c|}
\hline & Descriptor & Measure $( \pm 95 \% \mathrm{Cl})$ \\
\hline \multirow{6}{*}{$\begin{array}{l}\text { Fishing } \\
\text { activity }\end{array}$} & Mean fishing trip length (hours) & $6.4 \pm 0.2$ \\
\hline & CPUE fishing (kg / fisher / trip) & $7.4 \pm 1.2$ \\
\hline & Fishery yield (mt/y) & $2,700 \pm 436$ \\
\hline & Fishery yield (mt/y / km) & $14.2 \pm 2.3$ \\
\hline & CPUE reef gleaning (kg / woman / trip) & $14.4 \pm 2.5$ \\
\hline & Reef gleaning yield (t/y) & $955 \pm 166$ \\
\hline \multirow[t]{3}{*}{ Threats } & Number of fishers (men >15 years old) & $1,970 \mathrm{~V} \pm \mathrm{V} 438$ \\
\hline & $\begin{array}{l}\text { Number of women practicing reef } \\
\text { gleaning (women > } 15 \text { years old) }\end{array}$ & $570 \pm 205$ \\
\hline & Number of canoes & $1,902 \pm 317$ \\
\hline \multirow[t]{2}{*}{$\begin{array}{l}\text { Fish } \\
\text { consumption }\end{array}$} & $\begin{array}{l}\text { Quantity of fish consumption in the } \\
\text { fishers districts and villages } \\
\text { (kg/inhabitant/ } \mathrm{y} \text { ) }\end{array}$ & $50 \pm 4$ \\
\hline & $\begin{array}{l}\text { Proportion of the catch kept for sub- } \\
\text { sistence consumption }\end{array}$ & $26 \%$ \\
\hline
\end{tabular}


PERCEPTION SURVEY. Several trends were detected through the semi-structured interviews (Table 3). Over the last three decades, most of the respondents observed a general decrease in the abundance of resources (fish, sea cucumber, turtle, and lobster). They also perceived a lower mean size of targeted fish species, a reduction in coral and sea grass cover, and a decrease in the mean weight of the catch per trip and in the proportion of the catch kept for subsistence consumption. These trends lead to other impacts that have been also observed: they have to go further for fishing, especially north and south outside the bay, which increases the mean fishing trip duration. Respondents also observed increases in the number of fishers and canoes, and fishing trip frequency, as well as a trend towards the use of more efficient gears.

\section{DISCUSSION}

EVOLUTION OF TOLIARA BAY REEF FISHERY. MOst of the results of this study suggest that Toliara Bay is overfished, with indicators calculated with the participation of the local community pointing to a potential overexploitation. Trends perceived by reef users indicate the degradation of resources and habitats (decrease in quantity of resources, size of fish, coral and sea grass cover and CPUE) over the last three decades while fishing pressure has increased (increase in number of fishers, canoes, fishing gears, and increase in fishing trip distance, duration and frequency). Our household survey underlines the increased number of fishers $(1,970 \pm 438)$ in 2007 compared to previous studies: 1,556 in 1990 (Laroche and Ramananarivo 1995), and about 700 in 1972 (Bellemans 1989). These data provide insight into the general trend of fisher numbers but cannot lead to detailed analysis, as the methodologies were different for each study. This increased fishing effort probably comes from demographic growth and economic difficulties (Laroche et al. 1997), and confirm the trend observed by reef users through the perception survey. In 2007 there were 10.4 fishers $/ \mathrm{km}^{2}$ fishing in Toliara Bay, which is considered a high fishing pressure for reef ecosystems by McClanahan et al. (2002). The Toliara Bay fishery yield of $14.2 \pm 2.3 \mathrm{mt} / \mathrm{y} / \mathrm{km}^{2}$ exceeds the maximum sustainable yield that is estimated to be only $5 \mathrm{mt} / \mathrm{y} / \mathrm{km}^{2}$ for reef fisheries (Newton et al. 2007). These fishers, however, are not the only one to remove resources from Toliara Bay ecosystems, and $570 \pm 205$ women also practiced reef gleaning in 2007 . This activity obviously impacts benthic habitats and living resources (Vasseur 1997).

According to the perception survey, it seems that the fishers maintain their level of catch and revenue by increasing fishing effort and by keeping smaller proportions of their catches for subsistence consumption. Although CPUE in Toliara Bay seemed to be considerably higher in 1958, with one metric ton per trip frequently caught by gill-net (Lagouin 1959), it did not change significantly between 1989/1990 and 2006/2007. In 1989/1990 CPUE for line, gill-net and seine fishing, recorded from sampling of catch landings from the same beach as in our study, were $4.8 \pm 0.4,6.7 \pm 1.8$ and $8.2 \pm 1.9 \mathrm{~kg} /$ fisher/trip' respectively (Laroche and Ramananarivo 1995). Thus, the CPUE seems to have dropped dramatically between the 1960s and the 1980 s and remained relatively steady between the 1990s and 2007. As reported by the perception surveys, fishers have probably maintained CPUE by diversifying their fishing gears and using more efficient and less selective fishing gears (e.g., increase in net length and reduction of mesh size), increasing the fishing trip length and frequency, and targeting lower trophic level and value species. This is consistent with the analysis of the evolution in catch composition which shows that reef species or associated reef species (Siganidae and Caesionidae) that were dominant in seine captures in 1989/1990 (Laroche and Ramananarivo 1995) have been replaced by small coastal pelagic species (Clupeidae and Engraulidae) in 2006/2007. Another example is represented by the Acanthuridae, mostly low value species: they compose $18.2 \%$ of the gill-net catch during the cold season and $41.4 \%$ during the warm season in $2006 / 2007$ while they were less than $2 \%$ of the gill-net catch in 1989/1990 (Laroche and Ramananarivo 1995). The increasing occurrence of these herbivorous species (Harmelin-Vivien 1981) in catches constitutes a potential sign of a phase shift in the ecosystem of Toliara Bay from a coral dominated habitat to an

TABLE 3. Trends perceived during the last three decades by at least $50 \%$ of the reef users surveyed along the coast of Toliara Bay ( $\mathrm{n}=70$ interviews).

\begin{tabular}{|c|c|c|}
\hline Theme & Observed trend & $\begin{array}{c}\text { Percentage of informants having given } \\
\text { this information }\end{array}$ \\
\hline Fish consumption & Decrease in the proportion of the catch kept for subsistence consumption & 100 \\
\hline Fishing activity & Decrease in the mean weight of the catch per trip & 100 \\
\hline Threat & Increase in the number of fishers & 100 \\
\hline Reef resources & Decrease in abundance of targeted fish resources & 96 \\
\hline Threat & Increase in the number of canoes & 94 \\
\hline Habitat & Decrease in coral cover & 90 \\
\hline Habitat & Decrease in sea grass cover & 90 \\
\hline Fishing activity & Increase in the distance of the fishing zones from the landing sites & 69 \\
\hline Threat & Increase in the number of efficient fishing gears (e.g., nylon nets) & 63 \\
\hline Fishing activity & Increase in the mean fish trip duration & 60 \\
\hline Reef resources & Decrease of the mean size of targeted fish resources & 59 \\
\hline Reef resources & Decrease in abundance of targeted sea cucumbers' resources & 57 \\
\hline Reef resources & Decrease in abundance of turtles & 54 \\
\hline Reef resources & Decrease in abundance of lobsters & 54 \\
\hline Threat & Increase in fishing trip frequency & 50 \\
\hline
\end{tabular}


algae dominated habitat. This is consistent with the findings of Harris et al. (2010), who highlight a substantial decline in hard coral cover on the reefs of Toliara Bay over the last forty years, replaced to great extent by fleshy algae.

The findings of the present study largely agree with those of previous studies. Laroche and Ramananarivo (1995) and Laroche et al. (1997) found that Toliara Bay was heavily fished as indicated by the high fishing pressure and decreases in CPUE, fish size, and carnivorous species such as Serranidae relative to increases in herbivorous fishes such as Siganidae and Scaridae, and the general reduction of mesh size for seines and gill-nets and hook size for line fishing. This situation is worsening because households in the villages and fishing districts of Toliara Bay rely heavily on marine fish resources for nutrition $(50 \pm 4 \mathrm{~kg} /$ inhabitant/y) and income (Laroche et al. 1997). Unfortunately, fishing is not the only activity that has adverse impacts on Toliara Bay's ecosystems: exploitation of mangrove forests, sedimentation and pollution are also major causes of degradation (Vasseur et al. 1988). Different strategies have been implemented to address the problems of reef fisheries in the Toliara region. In the 1990s many development interventions were designed to help fishers in adopting new fishing techniques, to diversify the resources targeted, and to improve access to markets. Few of these activities, however, have been successfully implemented, probably because of a lack of support from local communities to proposed regulations that are mostly designed by external entities (Ranaivomanana 2006). This strategy led to some counterproductive results such as international development organizations promoting shark fisheries, which have made this fishery unsustainable today (McVean et al. 2006). Progressively, international conservation NGOs proposed a new approach to reconcile development and conservation (Chaboud 2006). This approach aimed at implementing marine protected areas and encouraging the participation of local communities, and has met with some recent successes, especially in rural regions north of Toliara. Further challenges remain, however, such as the legitimacy of the local representatives involved in the management of these marine protected areas and their financial sustainability that still heavily depend on external partners (Harris 2007, Belle et al. 2009). This approach is much more difficult to implement at an appropriate scale in urban regions such as Toliara Bay with a very high demographic and fishing pressure and severely degraded habitats. Thus, the protection of productive areas should be carried out alongside fishery sustainability development strategies that are socially acceptable, economically efficient and environmentally benign. Development does not necessarily mean more catches but should lead to increased selectivity, reduced by-catch, greater added value for each catch, and increases in labour efficiency. The analysis of catch composition in our study showed that line fishing targets high-value species (Lethrinidae, Carangidae, Siganidae, Lujanidae, Serranidae), pelagic species found at greater distance from the coast that are less dependent to the state of the habitats of the bay (Scombridae) and species with short life cycles that are less vulnerable to relatively high fishing pressure (Loliginidae). For these reasons and because it is a highly selective gear, line fishing should be promoted, and fishers should be trained and equipped to be able to reach offshore fishing areas. Small coastal pelagic species, such as members of the family Clupeidae, are a very important resource for the bay and are targeted both by gill-net (mostly during the warm season) and seine fishing. This seasonal and short life-cycle resource can support relatively high fishing pressure but should be better managed as the only legislation to date is an annual closure; fish processing should also be improved. Finally, the analysis of seine fishing catch composition highlights its very low selectivity (about $30 \%$ of the catch is represented by numerous families contributing to less than $3 \%$ to the total fish biomass caught in each season) and potential overlap in targeted resources with other fishing gears (e.g., Siganidae). This low selectivity for species is also true for sizes as seine fishing catches small and juvenile fishes because of its very narrow mesh size (less than $20 \mathrm{~mm}$ and a cod end made of fly-screen). This fishing gear should be regulated. In order to sustain the reef fishery of Toliara Bay, many recommendations have already been made by previous studies such as improving fish processing, development of an offshore fishery, creation of marine protected areas, banning destructive fishing gears, allocating exclusive fishing rights, implementation of anchored fish aggregating devices, creation of non-fishing activities (e.g., algae farming), investment in education programs and stabilization of population growth. These recommendations seem to be relevant because they both suggest activities to build reef resources and address socioeconomic drivers of decline (Cinner et al. 2009). This should also be included in a broader framework that seeks to address the problem of poverty in the region.

RELEVANCE OF PARTICIPATORY METHODS FOR FISHERIES

ASSESSMENT. By taking advantage of locally available knowledge and expertise, it is possible to quickly obtain a broad range of relevant information for the coarse characterization and assessment of the sustainability of a fishery, as the research in Toliara Bay and the analysis of the results demonstrate. Due to the involvement of the various reef users we were able to identify the impacts of fishing activity on resources (e.g., decrease in the size and availability of commercial species), ecosystems (e.g., decrease in coral cover and reef species abundance) and socio-economic systems (e.g., increase in number of fishers, canoes, fishing gears, and fishing trip distance, duration and frequency). It also provides information such as CPUE, fishery yield, quantity of fish consumption, and number of fishers. The experience also shows, however, that a major effort is required in terms of communication (rewarding and encouraging community members) and scientific supervision (establishment of data collection protocol, training, data quality checking, data analysis). Participatory monitoring does not mean the absence of involvement by scientists; human resources and skills in supervision and communication are crucial to ensure data quality. Further, the participatory methods tested in this study mostly provide imprecise or qualitative data that cannot always be used for statistical analysis and detailed description of a fishery. Much of the information on the fishery arising from household surveys, such as CPUE, is based on perceptions. These perceptions can be highly variable and lead to low precision in the data. It has also been shown that the estimated weight of the catch from snapshot surveys with fishers, to identify their perceptions of the average weight caught per trip, turned out to be from 42 to $64 \%$ higher than real catches (Lunn and Dearden 2006). Thus the CPUE and fishery yield data obtained through household surveys should be interpreted with caution. Besides their potential to improve 
knowledge of a fishery, the use of participatory assessment methods is also an efficient strategy to involve local communities in the management process. It has been demonstrated that when the community is involved in data collection programs the delivery of timely, readily understandable, usable, and relevant information to the community and decision-makers is enhanced and leads to improved management (Danielsen et al. 2005). At the same time the involvement of the local community in data collection activities also promotes education and awareness regarding the conservation and sustainable use of natural resources (Stepath 1999). For example, in this specific case study twelve classes from eight primary schools of fishing districts and villages along the coast of Toliara Bay were first taught and trained in class for half a day before being able to put their new knowledge into practice by investigating their household. Data are crucial in obtaining a picture of what the ecosystem upon which the small-scale fishery depends looks like and how it evolves. Equally as important is the need for awareness-raising within the local community, and especially the young generation, in order to help them to understand the importance, the natural dynamics and the vulnerability of their coastal resources (Rodriguez-Martinez and Ortiz 1999). Involving local communities in the participatory assessment of reef fishery sustainability contributes to both aspects.

\section{CONCLUSION}

Participatory assessment methods proved to be useful for collecting large amounts of relevant information regarding the fishery and its sustainability, quickly and at low cost, while raising the awareness of local communities in charge of the management of natural resources, building capacity and contributing to experience sharing. This is particularly relevant in the current context of the socio-political and economic crisis prevailing in Madagascar where funding and capacity are lacking for the management of small-scale fisheries. In Toliara, information was enhanced and improved thanks to the efforts of the local community and highlight the critical state of the ecosystems of the bay and the urgent need for action. Participatory assessment of small-scale fisheries could be replicated in other places in Madagascar, especially where data are scarce. This could help generate a better understanding of the direct and indirect economic and social values of these small-scale fisheries and the risks and foregone benefits associated with overfishing or ecosystem degradation, facilitate large spatial and temporal comparisons, and help develop relevant local marine resource management plans while promoting the involvement of the local community in this process.

\section{ACKNOWLEDGMENTS}

We thank the people of fishing districts and villages along the coast of Toliara Bay, especially the fishers, the wholesale merchants, the women practicing reef gleaning, the school teachers and children and the Institute of Fisheries and Marine Science of Toliara (IHSM). This work was supported by the Institut de Recherche pour le Développment (IRD) and the Agence Universitaire de la Francophonie (AUF). We also thank the editors of Madagascar Conservation \& Development and three anonymous reviewers for their useful comments.

\section{REFERENCES}

Belle, E. M., Stewart, G. W., De Ridder, B., Komeno, R. J.-L., Ramahatratra, F., Remy-Zephir, B. and Stein-Rostaing, R. D. 2009. Establishment of a community managed marine reserve in the Bay of Ranobe, southwest Madagascar. Madagascar Conservation \& Development 4: 31-37.

Bellemans, M. 1989. Résultats de l'enquête cadre des pêcheries traditionnelles côtières malgaches, 1987/1988 - bilan diagnostic des caractéristiques structurelles. Project PNUD/FAO/MAG/85/014 Report No. 4.

Brenier, A. 2009. Pertinence des approches participatives pour le suivi écosystémique des pêcheries récifales. Unpubl. Ph.D. thesis, Université Pierre et Marie Curie, Paris. Available at <http://www. crisponline.net/Portals/0/New\%20reports/FR\%202009\%20These\%20 Approches\%20Participatives.pdf>

Chaboud, C. 2006. Gérer et valoriser les ressources marines pour lutter contre la pauvreté. Études Rurales 178: 197-212.

Cinner, J. E., McClanahan, T. R., Daw, T. M., Graham, N. A. J., Maina, J. Wilson, S. K. and Hughes, T. P. 2009. Linking social and ecological systems to sustain coral reef fisheries. Current Biology 19, 3: 206-212. (doi:10.1016/j.cub.2008.11.055)

Danielsen, F., Jensen, A. E., Alviola, P. A., Balete, D. S., Mendoza, M., Tagtag, A., Custodio, C. and Enghoff, M. 2005. Does monitoring matter? A quantitative assessment of management decisions from locally-based monitoring of protected areas. Biodiversity and Conservation 14, 11: 2633-2652. (doi:10.1007/s10531-005-8392-z)

FAO (Food and Agriculture Organisation of the United Nations) 2003. The Ecosystem Approach to Fisheries. FAO, Rome, Technical Guidelines for Responsible Fisheries 4 Suppl. 2. Available at <http://www.fao.org/ docrep/005/Y4470E/Y4470E00.HTM>

Harmelin-Vivien, M. L. 1981. Trophic relationships of reef fishes in Tulear (Madagascar). Oceanologica Acta 4, 3: 365-374.

Harris, A. 2007. "To live with the Sea" - development of the Velondriake community-managed protected area network, southwest Madagascar. Madagascar Conservation \& Development 2, 1: 43-49.

Harris, A., Manahira, G., Sheppard, A., Gough, C. and Sheppard, C. 2010. Demise of Madagascar's once Great Barrier Reef - Change in coral reef condition over 40 years. Atoll Research Bulletin 574: 1-18.

Henry, G. T. 1990. Practical Sampling. Sage Publications Inc., Newbury Park, CA.

Hilborn, R. 2007. Moving to sustainability by learning from successful fisheries. Ambio 36, 4: 296-303. (doi:10.1579/00447447(2007)36[296:MTSBLF]2.0.CO;2)

Hosch, G. 2000. The Use of Students in Surveying Subsistence Fisheries - a Pacific Island Case Study. FAO Fisheries Circular No. 962. FAO, Rome. Available at <ftp://ftp.fao.org/docrep/fao/005/x9006e/ X9006E00.pdf>

Huntington, H. P. 1998. Observations on the utility of the semi-directive interview for documenting traditional ecological knowledge. Arctic 51, 3: 237-242.

Jackson, J. B. C., Kirby, M. X., Berger, W. H., Bjorndal, K. A., et al. 2001. Historical overfishing and the recent collapse of coastal ecosystems. Science 293, 5530: 629-637. (doi:10.1126/science.1059199)

Lagouin, Y. 1959. La pêche côtière malgache dans la région de Tuléar. Bulletin de Madagascar 153: 95-106.

Laroche, J. and Ramananarivo, N. 1995. A preliminary survey of the artisanal fishery on coral reefs of the Tulear Region (southwest Madagascar). Coral Reefs 14, 4: 193-200. (doi:10.1007/BF00334341)

Laroche, J., Razanoelisoa, J., Fauroux, E. and Rabenevanana, M. W. 1997. The reef fisheries surrounding the south-west coastal cities of Madagascar. Fisheries Management and Ecology 4, 4: 285-299. (doi:10.1046/j.1365-2400.1997.00051.x)

Le Manach, F., Gough, C., Harris, A., Humber, F., Harper, S. and Zeller, D. 2012 (2011). Unreported fishing, hungry people and political turmoil: the recipe for a food security crisis in Madagascar? Marine Policy 36, 1: 218-225. (doi:10.1016/j.marpol.2011.05.007)

Lunn, K. E. and Dearden, P. 2006. Monitoring small-scale marine fisheries: An example from Thailand's Ko Chang archipelago. Fisheries Research 77, 1: 60-71. (doi:10.1016/j.fishres.2005.08.009) 
Mathew, S. 2002. Small-scale fisheries perspectives on an ecosystem-based approach to fisheries management. In: Sinclair, M., Valdimarsson, G. (Eds.), Responsible Fisheries in the Marine Ecosystem. CAB International, Wallingford.

McClanahan, T., Polunin, N. and Done, T. 2002. Ecological states and the resilience of coral reefs. Conservation Ecology 6, 2: art 18. Available at <http://www.consecol.org/vol6/iss2/art18/>.

McVean, A. R., Walker, R. C. J. and Fanning, E. 2006. The traditional shark fisheries of southwest Madagascar: A study in the Toliara region. Fisheries Research 82, 1-3: 280-289. (doi:10.1016/j. fishres.2006.06.016)

Newton, K., Côté, I. M., Pilling, G. M., Jennings, S. and Dulvy, N. K. 2007. Current and future sustainability of island coral reef fisheries. Current Biology 17, 7: 655-658. (doi:10.1016/j.cub.2007.02.054)

Obura, D. O., Wells, S., Church, J. and Horrill, C. 2002. Monitoring of fish and fish catches by local fishermen in Kenya and Tanzania. Marine \& Freshwater Research 53: 215-222. (doi:10.1071/MF01151)

Pattengill-Semmens, C. V. and Semmens, B. X. 2003. Conservation and management applications of the reef volunteer fish monitoring program. Environmental Monitoring and Assessment 81: 43-50. (doi: 10.1023/A:1021300302208)

Pauly, D., Alder, J., Bennett, E., Christensen, V., Tyedmers, P. and Watson R. 2003. The future for fisheries. Science 302, 5649: 1359-1361. (doi:10.1126/science.1088667)

Pichon, M. 1978. Recherches sur les peuplements à dominance d'Anthozoaires dans les récifs coralliens de Tuléar (Madagascar). Atoll Research Bulletin 222: 1-447.

Ranaivomanana, L. N. J. 2006. Identification des conditions d'appropriation de la gestion durable des ressources naturelles et des écosystèmes : cas du Grand Récif de Toliara. Unpubl. Ph.D. thesis, Université de Toliara, Toliara, and Agrocampus-ouest, Rennes. Available at <http:// halieutique.agrocampus-ouest.fr/pdf/932.pdf>.

Rodriguez-Martinez, R. and Ortiz, L. M. 1999. Coral reef education in schools of Quintana Roo, Mexico. Ocean \& Coastal Management 42, 12 : 1061-1068. (doi:10.1016/S0964-5691(99)00061-7)

Sadovy, Y. 2005. Trouble on the reef: the imperative for managing vulnerable and valuable fisheries. Fish and Fisheries 6, 3: 167-185. (doi:10.1111/ j.1467-2979.2005.00186.X)

Stepath, C. M. 1999. Does community-based coral reef monitoring promote awareness? Proceedings of the Hawaii Coral Reef Monitoring Workshop, 9-11 June 1998, Honolulu: 33-38.

Uychiaoco, A. J., Arceo, H. O., Green, S. J., De la Cruz, M. T., Gaite, P. A. and Alino, P. M. 2005. Monitoring and evaluation of reef protected areas by local fishers in the Philippines: tightening the adaptive management cycle. Biodiversity and Conservation 14, 11: 2775-2794. (doi: 10.1007/ s10531-005-8414-x)

Vasseur, P. 1997. Écosystèmes côtiers en danger dans la région de Tuléar : analyse des agressions humaines et problèmes de gestion. In: Milieux et Sociétés dans le Sud-ouest de Madagascar. J. M. Lebigre (ed.) pp 97-120. Presses universitaires de Bordeaux (Collection Îles et Archipels 23), Bordeaux.

Vasseur, P., Gabrie, C. and Harmelin-Vivien, M. 1988. State of coral reefs and mangroves of the Tulear region (SW Madagascar): Assessment of human activities and suggestions for management. Proceedings 6th International 425 Coral Reef Symposium, Townsville 2: 421-426. Available at <http://www.reefbase.org/download/download. aspx? type $=10 \&$ docid $=10477>$.

Webb, E. L., Maliao, R. J. and Siar, S. V. 2004. Using local user perceptions to evaluate outcomes of protected area management in the Sagay Marine Reserve, Philippines. Environmental Conservation 31: 138-148. (doi: 10.1017/S0376892904001377)

Zeller, D., Booth, S., Craig, P. and Pauly, D. 2006. Reconstruction of coral reef fisheries catches in American Samoa, 1950-2002. Coral Reefs 25: 144-152. (doi: 10.1007/s00338-005-0067-4)

\section{SUPPLEMENTARY MATERIAL. AVAILABLE ONLINE ONLY.}

TABLE S1: Questionnaire used by children from eight public primary schools in the eight fishing districts and villages along the coast of Toliara Bay, to gather information on fishing effort, fishery yield, catch composition and fish consumption based on declarations of household members.

TABLE S2. Catch composition of the three main gears used by Toliara Bay traditional fishery estimated by participatory catch landing monitoring. Identification is to family level. 


\section{Participatory assessment of the Toliara Bay reef fishery, southwest Madagascar}

Ambroise Brenier, Jocelyne Ferraris and Jamal Mahafina

Correction to: Madagascar Conservation \& Development (2011) 6, 2: 60-67. http://dx.doi.org/10.4314/mcd.v6i2.4; published online 22 December 2011

On p. 63, 'mt/y' should be metric ton per year and not million ton per year.

Sentence should read "With the results of the household survey we were able to estimate a total production for the Toliara Bay fishery at 2,700 \pm 436 metric tons per year $(\mathrm{mt} / \mathrm{y})$, and the annual yield at $14.2 \pm 2.3 \mathrm{mt} / \mathrm{y} / \mathrm{km}^{2}$." 